\title{
THE UTILIZATION OF THE FIRST CEMETERY OF ATHENS IN THE EDUCATIONAL PROCESS: PRIMARY EDUCATION'S STUDENTS' PERCEPTIONS ${ }^{i}$
}

\author{
Lambrou, Chrysafia ${ }^{1}$, \\ Manesis, Nikolaos ${ }^{2 i i}$ \\ ${ }^{1}$ Directorate of Primary Education, \\ 93 ${ }^{\text {rd }}$ Primary School of Athens, \\ 11743, Athens, \\ Greece \\ ${ }^{2}$ Department of Education Studies \\ \& Social Work, \\ University of Patras, \\ 26500, Patras, \\ Greece
}

\begin{abstract}
:
The educational use of ancient necropolises is widespread in the western world, examining them in the light of archaeological, historical, artistic and environmental interest. However, western culture does not encourage school visits to modern cemeteries, even though they are historically and artistically important monuments, such as the First Cemetery of Athens. It was founded in the $19^{\text {th }}$ century on the basis of landscape architecture, adopting the aesthetics of Romanticism, as a product of a vision of an upgraded ideology for the realm of the dead and condense a wide field of learning. The educational world expresses strong doubts about the integration of the First Cemetery in the educational process, although it recognizes its multifaceted and multiple educational value. The purpose of this study is to investigate the perceptions of students in the 6th grade of Primary School about the Cemetery, to highlight the emotions that were developed and the results of the educational use of the visit to the Cemetery. The group semi-structured interview was used. The results showed the familiarity and the emotional connection that the $6^{\text {th }}$ grade students developed with the First Cemetery, showing their strong desire to visit it again. Thus, the value of using cemeteries in the educational process was highlighted.
\end{abstract}

Keywords: cemetery, cemetery art, educational program, educational process, elementary school students

\footnotetext{
i This study was produced from the Master's thesis of the first author, while the second author was cosupervisor.

ii Correspondence: email nmanesis@upatras.gr
} 


\section{Introduction}

Every society has shaped its own perceptions about death and the realm of the dead over time. These perceptions are part of a complex web of beliefs and customs (Stroebe \& Schut, 2001).

Historically, most people have preferred to place their dead in cemeteries (Mentzini, 2005), with the cities of the dead preceding the cities of the living (Daniil, 2008). The cemetery art has been flourished since the time of the ancient Necropolis of Alexandria (Venit, 1988). In Greece, cemetery art evolved into the majestic Mycenaean vaulted tombs, in the famous mounds of the Hellenistic period and, later, in exquisite specimens of necropolises, such as Kerameikos (Hatzopoulos, 2008).

Over the years, the cemetery art faded, until the 19th century when modern cemeteries appear. These are designed according to landscape architecture, aiming to bring urban residents closer to nature; cemetery was designed as a quiet space, adorned with sculptures, reminiscent of the pleasure, harmony, and grace of worldly life (Daniil, 2019). In this light, cemeteries are disconnected from the element of the macabre, from mourning and lamentation and are evaluated as places of art (Zavraka, 2009), strongly influenced by the classical artistic elements.

An excellent example of a modern cemetery in Greece is the First Cemetery of Athens, which is both a multicultural place of religious tolerance, hosting burials of many religious dogmas, as well as a historical testimony of events and personalities: there are tombs of national benefactors, military officers, politicians, artists, etc. (KardamitsiAdami \& Daniil, 2017).

\section{Literature Review}

In the course of history, people face the issue of mortality in different ways due to religious, cultural and social perceptions as well as cause of objective reasons such as space, economy, etc. (Daniil, 2008; Mentzini, 2005; Parkes, Laungani \& Young, 1997). Man's relationship to death is manifested in funeral customs, traditions, funeral legends, but also in everyday life ${ }^{\text {iii. }}$.

Worldwide folklore testifies to a number of popular beliefs that face death and cemeteries with skepticism. In ancient Greece there was a belief that the dead, if not burned or buried, transformed into an attacking and punishing creature (Skoubourdi, 2006). Homer talked about "condemnation" of the unburied dead in eternal wandering, finding no rest (Artemi, n.d.; Karytsa, 2014). A similar belief was established by the Church during the Middle Ages and relates to "vampirism" after aphorism or atheism or sinful life. The bodies of these dead do not decompose, and they are transformed into vampires, undead demonic creatures, who come out of their graves at night and spread horror, causing death and calamity (Gerouki, 2000; Politis, 2012).

\footnotetext{
iii For example, the Pontians celebrate "Tou Thoma sa tafia" and the Mexicans the Day of the Dead (Dia de los Muertos).
} 
Many more beliefs point to cemeteries as places where ghost appearances are observed (Politis, 2012; Skrivanos, 2017) and black magic ceremonies are performed. Perceptions of satanic practices are a remnant of Europe's ancient popular religions. The traces of these religions have never been erased, since the Church of the Middle Ages maintained the belief in magic, divination, spells and the invocation of supernatural powers, a phenomenon with uncontrollable dimensions and consequences (Anastasiou, n.d.; Bailey, 2001; Jolly, Raudvere \& Peters, 2002).

These popular beliefs still "feed" the human imagination with stories of terror and horror which unfold in cemeteries. A counterculture of death was thus developed (Clark, 1993; Parkes et al., 1997), a typical example of which are the horror films, enabling people to approach and distance themselves from death at the same time, by distorting and fictionalizing death (Parkes et al., 1997). These popular beliefs are related to confirmed phobias such as necrophobia, taphephobia, coimetrophobia (Athanasiadis, 2011; Mendoza, 2015).

Man's relationship to death or cemeteries is sometimes shaped by necessity. For

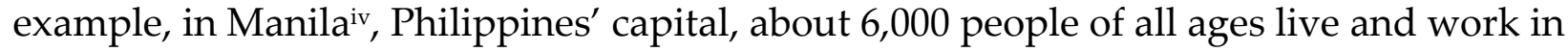
the largest cemetery, in makeshift buildings above and next to the graves, while the cemetery remains operationalv, due to poverty. Similarly, in Athens, during the German occupation, the need to survive pushed many Athenians of all ages to seek shelter in the First Cemetery of Athens.

The above confirm that there are differences in how people confront death and cemeteries (Daniil, 2008; Mentzini, 2005; Parkes et al., 1997; Stroebe \& Schut, 2001). Some maintain a friendly approach, others a phobic one, while others live next to death, a habit imposed by necessity.

In the past, consolation and relief from mourning was assigned to religion's representatives, while in modern western world death is a secular affair, even though there is often a tension between theological and rational beliefs (Walter, 1997). The advance in science and the extension of life expectancy have made the idea of death distant (Berry, Poortinga, Segall \& Dasen, 2002; Kazdin, 2000), therefore health professionals are now the ones people turn to, in order to maintain the illusion of eternal life (Alexias, 2000; Berry et al., 2002; Blanche \& Parkes, 1997), as science is still unable to interpret natural death (Parkes et al., 1997).

\footnotetext{
iv https://popaganda.gr/stories/katiki-sta-nekrotafia-stis-fillipines-zontas-anamesa-se-tafous/

v https://www.iefimerida.gr/news/141958/\%CE\%BF\%CE\%B9-

\%CE $\%$ AC $\%$ CE $\%$ BD $\%$ CE $\%$ B8\%CF\%81\%CF\%89\%CF\%80\%CE\%BF\%CE\%B9-\%CF\%84\%CF\%89\%CE\%BD\%CE $\%$ BA $\%$ CE $\%$ BF $\%$ CE $\%$ B $\%$ CE $\%$ BC $\%$ CE $\%$ B7\%CF\%84\%CE\%B7\%CF\%81\%CE\%AF\%CF\%89\%CE\%BD\%CF $\% 80 \%$ CE $\%$ BF\%CF\%85-\%CE\%AD\%CE\%BA\%CE\%B1\%CE\%BD\%CE\%B1\%CE\%BD-

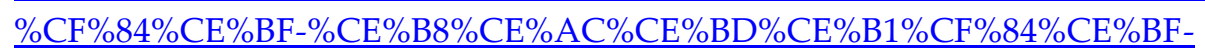
\%CF $\% 83 \% \mathrm{CF} \% 80 \% \mathrm{CE} \% \mathrm{AF} \% \mathrm{CF} \% 84 \% \mathrm{CE} \% \mathrm{~B} 9-\% \mathrm{CF} \% 84 \% \mathrm{CE} \% \mathrm{BF} \% \mathrm{CF} \% 85 \% \mathrm{CF} \% 82-$ $\% \mathrm{CF} \% 80 \% \mathrm{CE} \% \mathrm{~B} 1 \% \mathrm{CE} \% \mathrm{~B} 9 \% \mathrm{CE} \% \mathrm{~B} 4 \% \mathrm{CE} \% \mathrm{~B} 9 \% \mathrm{CE} \% \mathrm{AC}-$ \%CE\%B3\%CE\%B5\%CE\%BD\%CE\%BD\%CE\%B9\%CE\%BF\%CF\%8D\%CE\%BD\%CF\%84\%CE\%B1\%CE\%B9\%CE\%BA \%CE\%B1\%CE\%B9-\%CE\%BC\%CE\%B5\%CE\%B3\%CE\%B1\%CE\%BB
} 
In some cultures, including the Greek one, religion undertakes the ritual of death and funeral customs, with different, case by case, approaches to dealing with loss (Stroebe \& Schut, 2001), while several theological systems, such as Christianity and Buddhism, suggest reconciling with death (Gielen, 1997; Kazdin, 2000; Parkes et al., 1997). Moreover, for many small-scale societies, death is a transition that requires a series of rituals, practices, and customs that are not easily understood by western societies and often provoke deliberate attempts to stop them (Parkes et al., 1997; Rosenblatt, 2008).

Although some funeral customs and practices in the modern western world have been considered loathsome or unpleasant, there is nevertheless an attempt to preserve the cultural heritage by maintaining and reviving ancestral rituals and customs (Blanche \& Parkes, 1997).

Cemeteries are, for most peoples, the preferred burial sites of the dead (Mentzini, 2005). The burial of the dead was imposed for reasons of hygiene, but mainly due to the belief in the afterlife, as it allows the deceased to manage their body after biological death (Blanche \& Parkes, 1997; Metallinos, n.d.; Chrysostomos, 2019).

Burial rituals date back thousands of years, with the place and manner of burial reflecting social and class structures, habits and preferences (Daniil, 2008; Mentzini, 2005). The honorary burial is the subject of Sophocles' "Antigone" and is presented as a great issue in the Homeric Iliad (Artemi, n.d.; Karytsa, 2014; Sophocles, n.d.; Spanakou, 2019). Similar incidents are recorded in the "Iketides" of Euripides, in the naval battle of Arginousa, in the battle of Thermopylae (Euripides, 2021; Fields, 2007; Vourvachis, 2007).

The necropolises were built earlier than the cities of the living, while their positions in relation to the settlements vary, depending on the degree of reconciliation of each society with death (Daniil, 2008). The term "necropolis" comes from the homonymous suburb of ancient Alexandria, where the archeological dig brought to light impressive specimens of cemetery art (Mentzini, 2005; Venit, 1988).

In the course of history, burials took place inside and outside the temples (Tzinevraki, n.d.; Zavraka, 2009) with a class hierarchy as to the "beneficiaries" (Tzinevraki, n.d.). Those unfit for burial in the temples were destined for the cemeteries, in an attempt to associate them with obscene acts, on the verge of the supernatural (Gerouki, 2000; Tzinevraki, n.d.).

However, towards the end of the 18th century, the industrial revolution and urbanization in Europe relieves death of transcendental perceptions and separates it from ecclesiastical practices (Aries, 1988; Mentzini, 2005; Tzinevraki, n.d.). As a result, a new image for modern cemeteries comes out; cemeteries are designed based on landscape architecture and are decorated with sculptures (Daniil, 2019; Mentzini, 2005; Stefanou \& Stefanou, 2001; Zavraka, 2009).

The first example of the new trend of "modern cemeteries" is "Pere-Lachaise" in Paris (1804), which became a model for the evolution of cemeteries in the Anglo-Saxon world (Daniil, 2019; Mentzini, 2005; Stefanou \& Stefanou, 2001; Zavraka, 2009). It is the only designed free space within the City of Light (Stefanou \& Stefanou, 2001; Zavraka, 2009). From now on, cemeteries of special interest emerge, becoming part of the urban 
space and being relieved of the macabre and seen as places of aesthetic pleasure (Glover Lindsay, 2012; Stefanou \& Stefanou, 2001; Zavraka, 2009).

Modern cemeteries, especially in Greece, are far from meeting emotional needs, since they are the result of suffocating spatial and economic pressures and not a product of envisioning an upgraded space of the dead (Francis, Kellaher \& Neophytou, 2010; Stefanou \& Stefanou, 2001), as it occurred in Europe in the 19th century (Stefanou \& Stefanou, 2001).

Since the ancient times, people used to build monuments, which express the greatness of the one who is buried and exude love, tenderness and the pain of loss (Daniil, 2019; Hatzopoulos, 2008). Thus, the burial-cemetery art was developed, starting from Egypt and its emblematic monuments of pyramids. In the Mycenaean period, burial places evolved into the majestic, vaulted tombs and, in the Hellenistic years, into the famous mounds. Mausoleums were erected for the wealthy and famous people (Ziro, 2014; Hatzopoulos, 2008; Mentzini, 2005).

Burials in Greece usually took place in necropolises, such as Kerameikos, Aigai and Mycenae, which display wonderful burial monuments of architectural and artistic value. For those who died far from the city, brilliant cenotaphs were erected (Banou \& Bournias, 2014; Daniil, 2019; Mentzini, 2005).

During the Christian period, cemetery art is associated with worship and evolves from simple crosses and boxes to majestic buildings, which also served the needs of the Divine Liturgy. The most important burial monument of this kind is the Holy Sepulcher in Jerusalem. In Byzantine times, elaborate sculptural coffins or sarcophagi were used (Daniil, 2019; Ziro, 2014).

Reaching the 19th century, the influence of the classical artistic elements is obvious, shaping the neoclassical idiom. The burial types of the time are the epitaphs, the mourning spirit or angel of mourning, the temple-shaped monuments, the type of Lysikrates, the monuments with Egyptian elements, the full-length sculptural figures, the reclining female figure, busts, the cross-shaped tombstones and the burial type of newer morphology (Daniil, 2008; Glover Lindsay, 2012; Kardamitsi-Adami \& Daniil, 2017; Paraskevopoulou, 2015; Ziro, 2014).

Several cemeteries of this period reached top artistic expressions and are protected by UNESCO as World Heritage Sites. In this light, they are sites of attraction for travelers and legislation protects them (Draft Regulation for the Operation of Cemeteries of the Municipality of Athens, 2016; Regulation for the Operation of Municipal Cemeteries of Ermionida, n.d.; Draft Regulation for the Operation of Cemeteries of the Municipality of Kefalonia, 2018).

As a result, the Association of Significant Cemeteries of Europe was founded in 2010, networking the historical and artistically significant cemeteries, in order to promote them as an integral part of the world heritage (Association of significant cemeteries in Europe, n.d.). There is also the managing body of European Cemeteries Route (European Cemeteries Route, n.d.). Several Greek cemeteries are also included in the Association 
and the European Cemeteries Route (Association of Significant Cemeteries in Europe, n.d.; Greek cemeteries, 2017; European Cemeteries Route, n.d.).

Pere-Lachaise Cemetery in Paris was first established in 1804 as "a unique place that evokes meditation and daydreaming, imbued with art, culture and history." It welcomes annually more than 3 million visitors from all over the world, who visit the graves of world-famous people: artists, musicians and singers, writers, politicians, military officers, scientists, etc. (Pere Lachaise, n.d.). The cemetery remains operational to this day.

The Cemetery of Skiathos, the "Mnemouria", which operates to this day, has been the subject of many reports in recent years, both for its history and for the exquisite sculptures that adorn the tombs (Cemeteries celebrate, 2018; Rovva, 2018; The cemetery of Skiathos, a glyptotheque of memory, 2018). Its foundation dates back to around 1830 and, in 2013, it was characterized as a "Historic Site" by the Service of Modern Monuments and Technical Works of Thessaly (Greek cemeteries, 2017).

The First Cemetery of Athens, which operates to this day, is characterized as the largest and most important outdoor sculpture gallery in Greece, for some researchers even in Balkans. Based on the European standards of the time, it was founded in 1834 in the Mets area and summarizes the two leading artistic expressions of the urban cemeteries in the 19th century: the neoclassical monuments and the greenery (Daniil, 2019; Kardamitsi-Adami \& Daniil, 2017; Paraskevopoulou, 2015). 769 of its tombs have been characterized as artistically important and 157 as historically important (Athanasekou, 2018; Paraskevopoulou, 2015), a fact that makes the First Cemetery of Athens the most prominent cemetery in the country. The Church did not interfere in the work of the artists. Thus, the First Cemetery houses top monuments of all artistic currents (Daniil, 2019; Kardamitsi-Adami \& Daniil, 2017; Ziro, 2014). As for the personalities mentioned in the burial monuments, one could say that the recent history of the country unfolds page by page in the First Cemetery: scientists, military officers, politicians, leaders of the Greek Revolution of 1821, activists, artists, national benefactors, representatives of the church, art and literature (Daniil, 2019; Kardamitsi-Adami \& Daniil, 2017; Paraskevopoulou, 2015). An equally important issue that is promoted is the multiculturalism and religious tolerance, in which the First Cemetery operates, with burials of Jews, Protestants, Orthodox, Catholics, believers of other denominations and political burials (Daniil, 2008; Kardamitsi-Adami \& Daniil, 2017; Paraskevopoulou, 2015).

In the context of the promotion of thematic tourism, the term "Cemetery tourism" was recently introduced, with the experience of the Association of Significant Cemeteries of Europe offering the appropriate tools for its evaluation and implementation, helping to enhance visitation to cemeteries of historical and artistic importance. (Cemetery tourism, 2018).

A strong attraction to cemeteries is also a variety of attractive artistic or educational activities (exhibitions, presentations, performances, concerts, speeches, workshops, etc.), for which one is informed by the websites of the Association of Significant Cemeteries of Europe (n.d.) and Mount Auburn Cemetery (n.d.). 
Similar events in Greek cemeteries are recorded in one case in Skiathos Cemetery, in May 2018 (Rovva, 2018), and in two cases in the First Cemetery of Athens, in 2016 and 2017 (The city of the dead, 2016; Konstantopoulos, 2017).

Educational programs are defined as organized educational activities, formed around a thematic core and framed by active learning activities (Petropoulou, 2018; Zafeirakou, 2000).

As it is shown so far, cemeteries of historical and artistic significance are considered museum spaces, as they include a wide field of learning and are connected to the public (Nakou, 2001). Therefore, educational programs in cemeteries meet a variety of didactic and pedagogical goals and enhance the cultivation of multiple skills, attitudes and values, as students develop linguistic, cultural, social and technological literacy (Dimopoulou, Kirdi \& Svoronou, 2018), since they are constructively involved in the learning process in the form of work plans (project) approaching the learning areas interdisciplinary (Cross Thematic Curriculum Framework for Compulsory Education, 2003). They also develop communication and research skills, while accepting their origin, mother tongue and religion. They cultivate emotional maturity, as they realize the inevitable and reconcile with places of mourning, while at the same time they are encouraged to approach their metaphysical concerns and questions in a contemplative way. They observe the phenomenon of socio-economic stratification even in necropolises. They develop an emotional bond with the neighborhood and the city, studying their relationship with the history and memory of the neighborhood, the city and the country through the cemetery, as a main landmark. They aesthetically evaluate the cemetery and its monuments and connect it with the urban space and its evolution. They know the aesthetic currents, place them in a historical context and express themselves artistically through painting, sculpture, collage and video. Finally, they perceive the concept and the value of public space as active citizens and are made aware of the need to protect it (Kids 4 the city, n.d.).

More specifically, the didactic visit described in this research is related to the Curriculum of various courses, such as to the Language Curriculum, since the students put into operation the mechanisms of listening, answering, formulating questions, interpretation and argumentation on the occasion of the cemetery. The Mathematics Curriculum is also involved, as students utilize and expand their knowledge about the measurements of length, mass, time, surface and become familiar with their use in the cemetery and, consequently, in everyday life. The History Curriculum is involved, as they know the most important events (social, military, economic, political, diplomatic etc.) of modern and contemporary times and their protagonists who "rest" there. In addition, the Geography Curriculum can be explored by learning about the places of origin of the personalities that are "hosted" in the cemetery and distinguishing the interactions that develop between the neighborhood, the city, the country and the world. Students can also use and construct maps and recognize the basic characteristics of the symbolic representation of space. With regard to the Religious studies Curriculum, students realize the inevitable and are encouraged to express concerns and questions 
about life and death, by becoming familiar with the places of mourning and by learning about the funeral rites and traditions of Orthodoxy and other Confessions. Finally, cemeteries are associated to the Fine Arts' Curriculum, as students recognize and create images, forms and symbols of cemetery art (Cross Thematic Curriculum Framework for Compulsory Education, 2003).

Several school educational programs identified in the bibliography, took place in ancient necropolises and specifically in those of Kerameikos, Mycenae and Aigai, mentioned above (Aiges, n.d.; Educational programs of the Directorate of Museums of the Ministry of Culture, 2017; Kerameikos and Vrysaki, 2008. Educational programs of the Ephorate of Antiquities of Argolida, 2018).

On the other hand, tourist and cultural activities of Secondary schools, mainly abroad, are located in modern significant cemeteries (Association of Significant Cemeteries in Europe, n.d.; European Cemeteries Route, n.d.; Mount Auburn Cemetery, n.d.; National Cemetery Administration, n.d.; Rovva, 2018). However, there are no organized educational programs that treat cemeteries in a holistic way, in terms of their relationship with the historical, cultural, theological, political, social and geophysical context in which they were founded and evolved. In addition, none of the actions identified are addressed to primary school students.

The aim of this study, one of each kind in Greece and internationally, is to investigate the perceptions of primary school students about their "acquaintance" with the First Cemetery of Athens, to highlight the emotions that were developed during the educational visit at the Cemetery and the results of this visit. At the same time, this study aims to highlight the utilization of cemeteries in the educational process, as, although their educational value is recognized, educational visits of schoolchildren to mourning places are not encouraged (Lambrou, 2020).

Therefore, this research question was explored: "How do Primary School students evaluate their participation in an educational program related to the First Cemetery of Athens"?

\section{Material and Methods}

The participants of this study are 19 students of the 6th grade of the 93rd Primary School of Athens, who visited the First Cemetery of Athens with the rest of their class. The visit was within the educational program "Kids4thecity", which took place in the school year 2019-2020 in Primary and Secondary schools, under the auspices of the Technopolis of the Municipality of Athens. The First Cemetery was chosen by the class teacher after a discussion with the students, due to its proximity to the school unit and its status as the main landmark of the neighborhood where they live.

The students paid a three-hour educational visit to the Athens Cemetery. Then, they were interviewed at the school. Students' participation in the educational program, approved by the Institute of Educational Policy, was optional, while parents were informed in writing and consented. The anonymity of the participants was ensured, and all the rules of ethics were observed (Fontana \& Frey, 1998; Miles \& Huberman, 1994). 
Prior to the school visit, students were informed about the place of the visit and its purpose. The educational and entertaining tone of the visit was emphasized and a first "acquaintance" with the place was attempted, through the projection of photos and videos. Famous sculptures of the Cemetery were presented, as well as stories, myths and legends that involve the space, the sculptures and the artists, and also various historical elements, which concern both the Cemetery and the personalities it "hosts".

This preparation was followed by the school visit, which included activities of active and exploratory learning and educational games, utilizing experiential-multisensory methods, with worksheets that activate the mood for observation, exploration and discovery of the Cemetery and its sculptures. During the visit, the students were provided with additional information, which encouraged them to observe the space and to express thoughts, questions and queries. Discussions took place either in the field with the staff of the Cemetery (priests, guards, cleaners) or in the classroom, during the interview.

Students' interviews were conducted in the students' classroom the following day of the visit and it lasted three (3) teaching hours. The results are presented below. Thematic analysis was used for data analysis (Braun \& Clark, 2006; Tsiolis, 2017).

The focused group interview was chosen as the data collection tool, since the students, on the one hand, are motivated to participate with each other, and on the other hand, their interaction and cooperation helps to extract the best information about their perceptions and beliefs, as well as to understand the emotions which were developed (Creswell, 2011; Robson, 2007). Thus, impulsive answers and a wealth of verbal and nonverbal information were collected, while at the same time the interaction between the researcher and the interviewees was facilitated (Creswell, 2011; Robson, 2007). Active participation in a group interview is defined as participation in the discussion with questions, expressions of views, suggestions and ideas (O'Connor, Michaels, Chapin, \& Harbaugh, 2017). All 19 students participated in the interview, as, due to family or extracurricular activities, it was not possible to divide them into groups of four (4) to six (6) people, as it should have been (Creswell, 2011).

An interview protocol was drawn up, which included closed-ended and openended questions, which were differentiated and/or enriched during the interview, in order to encourage students to deepen their views and perceptions. The questions were formulated in simple and understandable language, they were short, clear, compatible with their experiences, non-guiding and non-ambiguous (Robson, 2007). In addition, Parrott's (2001) list of emotions was used, which was significantly modified and simplified, in order to make it easier for students to identify their emotions. For example, the feeling of love and the consequent emotions (affection, lust/sexual attraction, longing, care, passion, etc.) were removed, as well as emotions such as fervor, zeal, frenzy, ecstasy, in order for the vocabulary to be familiar to the students, but also to be accustomed to the expected emotions, without being disorienting.

In order to ensure the validity and reliability of the findings, the researcher had a long engagement with the issue, had ensured the students' trust, a detailed log was kept 
during the research. Also, the whole research process was examined by an external judge, the data were reviewed for any evidence that contradict the research findings to confirm the findings' accuracy. Moreover, the students checked the transcript data to confirm the fidelity of what they had said and, finally, the whole process is described in detail, so that it can be used in the future by another researcher (Cohen et al, 2007; Hassandra and Goudas, 2003; Symeou, 2007).

\section{Results and Discussion}

The following are the results of the group interview of the students who participated in an educational visit to the First Cemetery of Athens. The results extend in three axes: their contact with the cemeteries, but also with the First Cemetery of Athens, the emotions they developed and the educational use of the visit. The results are presented by axis.

\subsection{Contact with cemeteries}

The students were asked about any experiences from their contact with cemeteries in general and with the First Cemetery of Athens in particular. They were asked if they had visited cemeteries, who had accompanied them, the reasons why they visited them, how the site of a cemetery is described, what was their previous knowledge of the First Cemetery and what were their impressions of it, during their visit.

The first question concerned the visits of school-age children to cemeteries. As it can be seen from their answers to this and the next question, the students have relatively much contact with cemeteries:

"I have been in a cemetery many times." (M5)

"I have visited my village's cemetery, where my grandmother is buried." (M12)

"I have visited two cemeteries." (M8)

"I have been to a cemetery several times and that is why it was not the first time I went to... in a cemetery and specifically to the First Cemetery." (M4)

"I first went when I was 4 years old." (M16)

This was followed by a question about who accompanied them on their visits to cemeteries. Most have visited cemeteries with their parents, mainly for a loved one who passed away. Only one student replied that she had visited a cemetery as part of the scouts' actions:

"I went with my mom, my cousin... with my family in general." (M11) 
"With my mom, my uncle's daughters and them." (M3)

"I went for my grandmother and my grandfather's brother." (M5)

"For my mom's uncle, to look at his grave." (M9)

"We visited our great-grandmothers and great-grandfathers and my grandfather and my uncle." (M17)

"To bury our loved ones." (M8)

"Not for a funeral. Just to see the tomb and light the candle." (M14)

"I had visited one with my family, but I had visited another one with the scouts, because we played a "City Game" with clues. (...) They hide envelopes with clues for us in the city and we solve mysteries." (M12)

The next question was about the description of a cemetery. They describe it as a place with narrow spaces, where the tombs are very close to each other, there are narrow corridors and trees and the noise comes mainly from outside:

"There were tombs, one next to the other. Some were abandoned, they had... they were full of plants. There were many crosses and many people, mourning their loved ones." (M12)

"It is abandoned, there is also one grave next to the other, it is a small space, one must walk very narrowly. And generally, there is a lot of noise, a lot of noise. (...) Outside, from the cars." (M7)

"I have visited two cemeteries, but both are still in good condition. But it is really one grave next to the other and it is narrow." (M9)

"It has trees, plants. It has... In front... there are the priests of the church. And it has an ossuary." (M14)

"Ehm... there are narrow corridors. There are priests there and people who maintain it. And all that." (M5)

The students were then asked about their contact with the First Cemetery of Athens. The first question was about their previous knowledge of the Cemetery. The answers of the majority refer to its historicity and to famous sculptures or personalities 
that "rest" there, mainly because it is a landmark of the neighborhood where they live, while few students limit their references to its function as a cemetery:

"I went to see the statues, and in particular the ones of the fighters of 1821." (M13)

"Yes. Yes, I had heard about it from my parents ... " (M4)

"I had heard from my parents that the tomb of Vougiouklaki and the Sleeping Beauty of Halepa was there." (M18)

"I had heard things from the children who had gone to the Cemetery, but they did not tell me many details." (M16)

"I have heard about it, because I pass it by to go home. And that is why my parents told me that there is the First Cemetery, where Aliki Vougiouklaki is also buried." (M7)

"We were passing by far away and my mom shows me that by that road is the Cemetery. The First. (...) I think she has not visited it." (M14)

"I went to visit my grandfather, my great-grandfather." (M1)

"I went for the funeral of a relative of my dad's." (M12)

A question followed about their impressions of the First Cemetery, when they visited it. Their answers show the satisfaction they gained, mainly due to its museum nature:

"At first, I thought it would be like the other cemeteries, which do not have so much greenery, statues and, then, when I went in, I liked it very much, because it did not remind me so much of a cemetery and I thought as if I had gone for a walk with my class. (...) In an open-air museum, which was built on a... hill..." (M4)

"It was a bit pleasant, because there were also statues above the graves." (M15)

"It did not look like you were in a cemetery, but it was as if you were inside a museum, which has statues and depicted certain eras and some fighters." (M5)

"During our walk, it reminded me of a museum, and I liked it very much." (M8)

"There are not many cemeteries like the First." (M17) 
"I want to say that walking among graves is not a bad thing, because we also walked among statues, so it was pleasant for me." (M2)

"If the tombs are tidy, it is not so unpleasant to walk among them." (M3)

Completing the first axis that concerned the contact of students with cemeteries, we conclude that they perceive cemeteries as places of religion, farewell and communication with the deceased, noting the social obligation to participate in religious ceremonies related to the death of loved ones, as well as caring for their tombs. They also believe that visits to cemeteries cultivate familiarity with the site. In addition, despite the disappointing image of modern cemeteries, the students talk about their excellent impressions of the First Cemetery, emphasizing its uniqueness, as they focus on the cemetery art, the prominent personalities it "hosts" and the vegetation, which make it a museum area and an integral part of modern and contemporary history.

\subsection{Emotions}

The second axis presents the thoughts and feelings that were developed on the announcement of the visit to the First Cemetery, the emotions that emerged during the visit and after the visit.

The first question was about the thoughts of the students when they were informed about the visit to the First Cemetery. From their answers arise mixed thoughts, ranging from a pleasant anticipation of visiting a place of art, to moderation due to the reputation of the Cemetery, but also a surprise, judging the place subversive or unsuitable for a school visit:

"I thought it would be nice to visit a place with so many statues." (M9)

"I had heard things, but I did not believe them. (...) That there are statues... and beautiful things." (M3)

"At first, I thought it was weird to visit a cemetery with my school class, but then it seemed like a good idea. (...) Because it is a bit strange for someone to go for a walk in a cemetery, let alone with one's school class. I do not know. (...) Strange, I do not know how to explain it. (...) Eh... ok. In short, that we'll visit the dead." (M12)

The students were then asked how they felt when they were informed of the visit to the Cemetery. From their answers mainly phobic emotions are derived, such as shock, shivering, anxiety, horror, terror. However, there were some students who reported that they did not have any negative emotion:

"Eh, (...) a little shock at first, because... whoa!" (M5) 
"Because we have an image, I think, most students in the classroom, of the other cemeteries, we believe that the best excursion would not be to go to a cemetery." (M14)

"I have not been to other cemeteries, but I think it will be a little creepy." (M11)

"Before we reached the Cemetery, I had a fear, specifically shock and anxiety of what I would face." (M7)

"I was not afraid, but I was a little freaked out, because we were going to see the graves in a cemetery and I did not like that, because we would be walking among graves and it is a little creepy. (...) It is a little sad to see dead people - that is, you do not actually see them, you see their graves and it is sad." (M16)

"When you visit a cemetery, you see a grave next to a grave and it is not a nice picture. (...) And as you see the graves next to each other, you say "Virgin Mary!" (M2)

"The truth is that I, personally, am a little scared. (...) Because when I enter a cemetery, I don't know, I shiver at that moment and, I don't know, I cannot stay there for long. In fact, I don't know anyone who can stay there for long! "Usually you go to mourn someone, so... generally it is not a nice feeling when we go to the cemetery." (M10)

"I first went when I was 4 years old and I had no fear." (M15)

"It's not bad to visit a cemetery for a walk." (M6)

"As I had been there before, I was happy and I was wondering if something had changed, if the place had been maintained more." (M17)

The students were asked, on the occasion of reporting their emotions on the announcement of the visit to the First Cemetery, about the origin of these feelings. They referred extensively to horror films, as they financially exploit the fascination that superstitions and beliefs of death and cemeteries exert on man:

"In children's shows, the cemetery is presented as a dark place which makes you scared, because there are monsters and other such things and it is scary." (M12)

"When I first went to a cemetery, at first, I thought it would be like in children's shows, with hands coming out (laughs) of the ground. Hands of zombies, of the dead. (...) It's like when a dead person comes back to life and wants to eat your brain. (...) It spreads your head open and eats it!" (M2) 
Teacher: Why do you think cemeteries are presented in this way in movies, on television, maybe even in some books?

"I think because it is a place with dead people, so they think they can show that it is scary and that the dead come to life over there." (M3)

"We don't feel well when we visit a cemetery and that's why the movies started to get scary." (M14)

Teacher: Do people gain anything by making horror films?

"They make money. The viewers would like to watch... If they want their adrenaline to rise." (M5)

"Horror movies are generally seen by a lot of people, so it's normal to make them, because they earn money, and they have a lot of viewers." (M9)

"I, for example, when I came back from the Cemetery, I was thinking about these monsters and, when I closed my eyes to sleep, the statues came to me in a frightening form." (M7)

"These movies make money on television. (...) Some people may like the feeling of being scared." (M18)

"There are also horror games on computers that you have to pay for and people who make them get more money..." (M14)

"I like to watch such movies, but I'm more scared of those which show true stories. (...) I mean ghosts and... paranormal things." (M10)

Regarding the students' emotions that were developed during the visit, it seems that there is a deviation from the initial feelings, due to the preparation at school for the upcoming visit, as the initial fear was eliminated or reduced to simple discomfort:

"After our teacher explained to us that there are statues in the Cemetery, I was excited and couldn't wait to go." (M10)

"I was excited and wanted to go." (M2)

"No fear. Not at all." (M8)

"I didn't feel anything particular." (M6)

"I wasn't too scared, but I was worried. (...) Because people have been buried there and families have lost their loved ones." (M5) 
"I, at some point, wanted to leave, because I remembered a relative of mine, but it just crossed my mind and then it was gone." (M12)

"Not fear, but at some point, when we passed by a small mausoleum, some children and I thought what it would be like to be there at night and... we were a little scared... just that." (M14)

"I didn't exactly want to leave, but as I was walking, I turned and saw this statue that his hands were like a mummy's, ehm... and I was scared. (laughter) I turned my head and saw this, and I was shaken." (laughter) (M3)

This decrease in phobic emotions also arose as a result of the charm exerted on the students by the cemetery art and the particularity of the First Cemetery:

"Yes, I liked the way the tombs were decorated with statues and various other things." (M3)

"If the tombs are tidy, it is not so unpleasant to walk among them." (M15)

"After all, it's not so bad to walk among graves. I'm not saying it's normal, but, unless your own people are buried there, you don't feel anything special." (M4)

"After all, they are not creepy, because they beautify... the sculptures beautify the tombs." (M8)

"I felt sadness and misery for the people who passed away." (M9)

"You're just upset when you have lost a dear person, who is buried in that cemetery." (M6)

"It is strange not to feel anything there, because the First Cemetery is not the same as other cemeteries." (M1)

"When we visited the Cemetery, I felt... a little anxiety, a little fear, because it is not nice to see the graves of others, of the dead, but also a little excitement about what we were about to see over there. (...) When we were still outside and a little when we entered." (M12)

The last question was about the students' emotions after the visit. The elimination of fear, their satisfaction and the promotion of the First Cemetery of Athens as a prominent museum space can be deduced from their answers:

"Fine, because we saw statues of great people, whom we had known in history." (M5) 
"I too, because it was the first time, I saw a cemetery decorated with statues, with plants." (M12)

"Pleasure from what I saw, but also a shudder... eh... thinking about the people who have passed away." (M14)

"I feel satisfied, because I had never been to such a cemetery before, and I liked it very much." (M7)

"I feel satisfied, as I did not expect anything less from the First Cemetery." (M1)

"I didn't expect the visit to be so great, I liked it very much and I feel happy that I had the opportunity to see the First Cemetery." (M13)

Concluding the second axis, it is noted that the majority of the students initially accepted the announcement of the visit to the First Cemetery of Athens with skepticism, as they were influenced by horror films, which are based on popular beliefs related to death and the realms of the dead. However, the preparation they had at school as well as the visit itself made the initial phobic emotions diminish and gradually give way to feelings of joy and satisfaction, which stemmed from the pleasure evoked by the cemetery art.

\subsection{The educational use of the visit}

The third axis that was investigated concerned the knowledge students acquired, their thoughts, the questions that arose during the visit, their desire to repeat the visit and the suggestions for its improvement.

The first question was about what the students could remember from what they saw or heard during the visit. Their answers during the interview and their answers on the worksheets show the interdisciplinary connection of the new knowledge with the various cognitive objects, but also the perception that the location and the decoration of the graves is connected with the socio-economic origin of their families:

"That it was built during the era of Romanticism. There were statues, trees, plants..." (M6)

"Very important fighters of '21 are buried there." (M10)

"We visit the cemetery in order to light a candle... at Easter..." (M5)

"It was the first cemetery built in Athens." (M13)

"It was founded after the Greek Revolution of 1821." (M16) 
"We saw statues of great people, whom we had known in History; Kolokotronis, Odysseas Androutsos, Kanaris, Giannoulis Halepas, Adamantios Korais, Papamichael, Emmanuel Xanthos, Markos Botsaris, the Trikoupis family." (M9)

"There were statues... sculptures and... they were very beautiful, and I thought that, for someone to do it... that is, for the family to decide... that they want something beautiful, they would obviously be rich." (M1)

"I noticed that Papamichael's tomb... eh... was not so... how to say... groomed, it did not have a statue, even a small one. Yes, it didn't have anything special in relation to the others." (M3)

"Uphill, the sculptures we saw were more... were not as beautiful as those downhill, because the higher we were going, the poorer were the families." (M12)

The students were then asked if they would like to visit the First Cemetery again and for which reasons. Their answers clearly indicate their strong desire to complete the tour of the tombs of famous personalities:

"I really enjoyed this experience and would love to go with my class again." (M11)

"I too... I too want to go again." (M2)

"I would go again to see Aliki Vougiouklaki too." (M13)

"I would like to see some other celebrities we did not see." (M19)

The interview ended with the students' suggestions for improvement or enrichment of their next visit to the First Cemetery. The majority of students proposed an extension of the space to be visited but also of the time, in order to include more personalities and sculptures. The rest of the suggestions were related to key elements of the learning process that the students considered important, such as teamwork, interaction, parental involvement and experiential-multi-sensory, playful learning:

"It would be nice to go even higher, to see the statues we did not see." (M1)

"To see more tombs and more statues, as the other children said too." (M17)

"To see some celebrities, some other celebrities that we did not have time to see." (M7)

"To be more cooperative next time and to have more time." (M4) 
"To have more time to see other statues and have my dad with me. (smile)" (M6)

"Play more games, such as treasure hunt." (M10)

"Let's not analyze things so much, because it was a bit boring." (M12)

In conclusion, it turns out that students recognize the value, usefulness and the need to integrate collaborative and experiential methods into the everyday educational practice, which they already know. They also suggest improvements in the organization and prosecution of the next visit to the Cemetery, which they look forward to.

\section{Recommendations}

Future research could focus on an ethnographic study, in various geographical areas of Greece and/or abroad that host significant modern cemeteries, as well as on older children and adolescents.

\section{Conclusion}

The students perceive cemeteries as a place of religious worship, farewell and communication with the deceased. They point out the social obligation to participate in religious ceremonies related to the death of relatives, emphasizing the moral obligation of the living to visit them for the care of the tombs and for religious rituals. For most students, cemeteries are associated with the loss of loved ones, thus evoking memories, unpleasant thoughts and intense emotional tension (Stroebe \& Schut, 2001).

They acknowledge that the First Cemetery of Athens is by far different from other cemeteries they have visited. Despite their initial surprise, they present their educational visit to the First Cemetery as a unique experience. They characterize it as an open-air museum with plants and statues (Daniil, 2019; Mentzini, 2005; Stefanou \& Stefanou, 2001), which depicts different historical eras. They vividly describe their thoughts, emotions, findings and overall impressions, expressing a strong desire to repeat the educational visit and at the same time formulating their suggestions for the improvement of the educational program. However, while some students reported that their initial fear was eliminated, others testified that it was reduced to mere discomfort, without disappearing. Such answers reinforce the view that legends and popular beliefs that underlie the fear of death and cemeteries, no matter how rationalized, remain deeply rooted in popular mind (Gerouki, 2000; Mendoza, 2015; Parkes et al., 1997; Politis, 2012).

In addition, their answers highlight the value of educational visits to modern cemeteries, as many of the teaching and pedagogical goals of the program were met. Communication and research skills were developed, the interdisciplinary approach of knowledge, active participation, multi-sensory-experiential approach, teamwork and 
interaction were utilized, which were recognized as key elements of the learning process (Cross Thematic Curriculum Framework for Compulsory Education, 2003).

They realized the inevitability of death and cultivated emotional maturity, while examining a museum but also a mourning place. They were encouraged to recognize and express thoughts, emotions and metaphysical concerns and questions about life and death that have long preoccupied man (Parkes et al., 1997). They found that the phenomenon of socio-economic stratification can be perceived even in the realms of the dead. They got to know their relationship with the history and memory of the neighborhood, the city (Kids4thecity, n.d.) and the country through the Cemetery, as a monumental landmark with a constant presence in the historical, social and political life of modern and contemporary years. They aesthetically evaluated the Cemetery at the level of urban planning, architecture, art, as well as its monuments and cemetery art in general (Daniil, 2008; Kardamitsi-Adami \& Daniil, 2017; Ziro, 2014), and connected it with the urban space and its development with the Cemetery as the core.

\section{Limitations}

The research was time bound and limited in space, as it focused on the First Cemetery of Athens, while the sampling was intentional. Nevertheless, the findings fill the gap regarding students' perceptions of the educational use of modern, historically and artistically significant cemeteries.

\section{Acknowledgements}

We thank the students and their parents for participating in the research, the staff of the First Cemetery of Athens (priests, guards, cleaners), who warmly welcomed and facilitated the school visit, and Ms. Eleni Lambrou for her valuable help in translating the text into English.

\section{Conflict of Interest Statement}

The authors declare no conflicts of interests.

\section{About the Author(s)}

Chrysafia Lambrou, Med, serves as a primary school teacher at the $93^{\text {rd }}$ Primary School of Athens. She is interested in new teaching methodology and her research work refers to modern technologies and theatrical game in education, to environmental, cultural and art education and to innovative educational methods. She has given speeches at seminars (9) and she has published articles in conference proceedings (6), on the above topics.

Dr. Nikolaos Manesis, serves as a laboratory teaching staff in the Department of Education and Social Work of University of Patras. His research work refers to topics such as teaching methodology, differentiated teaching, curricula, educational evaluation, educational policy, inequality in education, school and social exclusion, relationships, and exchanges of activities in the classroom, the teachers' role, family and school 
relations, gender and diversity. He has participated in European Programs. He has published books (6), articles in international \& Greek journals (33) and conference proceedings (47), on the above topics.

\section{References}

Aigai. (n.d.). (in Greek). Retrieved from https://www.aigai.gr/el/history/aiges/vergina Alexias, G. (2000). About life and death. Athens: Greek Letters (in Greek).

Anastasiou, M. (n.d.). Witches in the Middle Ages. Academia.edu. (in Greek). Retrieved from

https://www.academia.edu/5697886/\%CE\%9F\%CE\%99 \%CE\%9C\%CE\%91\%CE\% 93\%CE\%99\%CE\%A3\%CE\%A3\%CE\%95\%CE\%A3 \%CE\%A3\%CE\%A4\%CE\%9F \%CE\%9C\%CE\%95\%CE\%A3\%CE\%91\%CE\%99\%CE\%A9\%CE\%9D\%CE\%91

Aries, F. (1988). Essays on death in the West. (trans.: K. Lampsa). Athens: Gull (in Greek).

Artemi, E. (n.d.). The burial of the dead during the Homeric and later Christian years. (in Greek). Retrieved from http://users.sch.gr/amalsk/Arheio/12Issue/4EthimaTafis.pdf

Association of significant cemeteries in Europe. (n.d.). Retrieved from http://www.significantcemeteries.org/

Athanasekou, M. (2018). The ethical issues of removing tombstones from their historical environment. (in Greek). Retrieved from https://www.monumenta.org/article.php?IssueID=4\&ArticleID=1069\&CategoryI $\underline{\mathrm{D}=35 \& \text { lang }=g r}$

Athanasiadis, K. (2011). Phobias. (in Greek). Retrieved from https://kyriakosathanasiadis.wordpress.com/2011/08/18/66077493/

Bailey, M. D. (2001, October). From Sorcery to Witchcraft: Clerical Conceptions of Magic in the Later Middle Ages. Speculum. A journal of Medieval Studies. 76(4). Retrieved from

https://www.journals.uchicago.edu/doi/abs/10.2307/2903617?journalCode=spc

Banou, E., \& Bournias, L. (2014). Kerameikos. (in Greek). Retrieved from https://www.latsis-foundation.org/content/elib/book 2/kerameikos gr.pdf

Berry, J. W., Poortinga, Y. H., Segall, M. H., \& Dasen, P. R. (2002). Cross-cultural psychology. Research and applications. (2 ${ }^{\text {nd }}$ edition). Cambridge, UK: Cambridge University Press.

Blanche, H. T., \& Parkes, C. M. (1997). Christianity. In C. M. Parkes, P. Laungani \& B. Young (Eds.), Death and Bereavement Across Cultures (pp. 131-146). London and New York: Routledge.

Braun, V., \& Clarke, V. (2006). Using Thematic Analysis in Psychology. Qualitative Research in Psychology, 3(2), 77-101.Clark, D. (1993). The sociology of death. Oxford, UK: Blackwell Publishers. 
Cemeteries celebrate. (2018). (in Greek). Retrieved from http://newpost.gr/art/672367/takoimhthria-giortazoyn-apo-tis-15-ma-oy

Cemetery tourism. (2018). (in Greek). Retrieved from https://www.culture.gr/el/service/SitePages/view.aspx?iID=3400

Chrysostomos. (2019). Burial or cremation of the dead? (in Greek). Retrieved from https://www.pemptousia.gr/2019/10/tafi-i-kafsi-ton-nekron/

Cohen, L., Manion, L., \& Morrison, K. (2007). Research Methods in Education (6th ed.). New York. N.Y.: Routledge.

Creswell, J. W. (2011). Research in education: Design, conduct and evaluation of quantitative and qualitative research. Athens: Ion (in Greek).

Cross Thematic Curriculum Framework for Compulsory Education. (2003) (in Greek). Retrieved from http://www.pi-schools.gr/programs/depps/

Daniil, M. (2008). First Cemetery of Athens, the peaceful coexistence of different cultures. (in Greek).

Retrieved

from

https://www.monumenta.org/article.php?IssueID=4\&lang=gr\&CategoryID=7\&A rticleID $=274$

Daniil, M. (2019). The first cemetery of Athens: Highlighting a monumental area. In: Georgitsoyanni E. (Ed.). Ancient Greek Art and European Funerary Art (pp. 371-398). Cambridge, UK: Cambridge Scholars Publishing.

Dimopoulou, M., Kirdi, K., \& Svoronou, E. (2018). The child, the city and the monuments. Guide to educational activities for Primary Education. Athens: Technopolis of the Municipality of Athens and Piraeus Group Cultural Foundation (in Greek).

Draft Regulation for the Operation of Cemeteries of the Municipality of Athens. (2016). (in Greek). Retrieved from http://www.cityofathens.gr/sites/default/files/\%20\%CE\%9A\%CE\%91\%CE\%9D\% CE\%9F\%CE\%9D\%CE\%99\%CE\%A3\%CE\%9C\%CE\%9F\%CE\%A5\%20\%CE\%9B\%C E\%95\%CE\%99\%CE\%A4\%CE\%9F\%CE\%A5\%CE\%A1\%CE\%93\%CE\%99\%CE\%91 \%CE\%A3\%20\%CE\%9A\%CE\%9F\%CE\%99\%CE\%9C\%CE\%97\%CE\%A4\%CE\%97\% CE\%A1\%CE\%99\%CE\%A9\%CE\%9D.pdf

Draft Regulation for the Operation of Cemeteries of the Municipality of Kefalonia. (2018). (in Greek). Retrieved from http://www.kefallonia.gov.gr/media/gkontogi/\%CE\%94\%CE\%A3/173\%2018\%20 \%20\%CE\%A9\%CE\%A369\%CE\%A9\%CE\%955\%CE\%94\%CE\%9B5\%20\%20\%CE\%9F\%CE\%A1\%CE\%98\%CE\%97\%20\%CE\%95\% CE\%A0\%CE\%91\%CE\%9D\%CE\%91\%CE\%9B\%CE\%97\%CE\%A8\%CE\%97.pdf

Educational programs of the Directorate of Museums of the Ministry of Culture. (2017). (in Greek). Retrieved from http://edugate.minedu.gov.gr/images/docs/episkepseis/athina/dwrean/YPPOA 20162017.pdf

Educational programs of the Ephorate of Antiquities of Argolida. (2018). (in Greek). Retrieved from https://www.argolisculture.gr/el/ekpaideytika- 
programmata/ekpaideytika-programmata-tis-eforeias-arhaiotiton-argolidas-giato-sholiko-etos-2018-2019/

Euripides. (2021). Iketides. Athens: National Bank Educational Foundation (in Greek).

European Cemeteries Route. (n.d.). Retrieved from https://cemeteriesroute.eu/europeancemeteries-route.aspx

Fields, N. (2007). Thermopylae 480 BC: Last stand of the 300. Oxford: Osprey Publishing. Fontana, A. \& Frey, J. (1998). Interviewing: The Art of Science. In Denzin, N \& Lincoln, Y (Eds.). (1998) Collecting and interpreting qualitative materials: 47-78. London: Sage.

Francis, D., Kellaher, L. \& Neophytou, G. (2010, August 19). Sustaining cemeteries: The user perspective. Mortality, 5:1, 34-52, doi: 10.1080/713685994

Gerouki, A. (2000). Metaphysical fears and their management: vaporized-vampires. In: Collective Fears in History (pp. 13-34). Athens: National Research Foundation (in Greek).

Gielen, U. P. (1997). A death on the roof of the world: The perspective of Tibetan Buddhism. In C. M. Parkes, P. Laungani \& B. Young (Eds.), Death and Bereavement Across Cultures (pp. 73-97). London and New York: Routledge.

Glover Lindsay, S. (2012). Funerary arts and tomb cult. Living with the dead in France, 17501870. Farnham/Burlington, Vermont: Ashgate.

Greek Cemeteries (2017). (in Greek). Retrieved from https://www.culture.gr/el/Information/SitePages/view.aspx?nID=1907

Hassandra, M., \& Goudas, M. (2003). Criteria of validity and reliability in qualitative interpretive research. Scientific Yearbook of the Psychological Society of Northern Greece, 2, 31-48. (in Greek). Retrieved from http://lab.pe.uth.gr/psych/images/stories/pdf/various/kritiria egyrotitas kai aksi opistias stin poiotiki ereyna.pdf

Hatzopoulos, M. (2008). The burial of the dead (at Vergina) or the unending controversy on the identity of the occupants of tomb II. Tekmeria, 9, 91-118. doi: http://dx.doi.org/10.12681/tekmeria.216

Jolly, K., Raudvere, C. \& Peters, E. (2002). Witchcraft and Magic in Europe. The Middle Ages. London: The Athlone Press.

Kardamitsi-Adami, M. \& Daniil, M. (2017). The First Cemetery of Athens. Guide to its monuments and history. Athens: Olkos - Hellenic Society of Environment and Culture (in Greek).

Karytsa, A. (2014). The burial and cremation of the dead in antiquity. (in Greek). Retrieved from https://www.schooltime.gr/2014/08/24/tafi-kai-kausi-nekron-stin-arxaiotita/

Kazdin, A. E. (2000). Encyclopedia of Psychology. Oxford, UK: Oxford University Press.

Kerameikos and Vrysaki. (2008). (in Greek). Retrieved from https://www.culture.gr/el/service/SitePages/view.aspx?iID=3295

Kids4thecity. (n.d.). (in Greek). Retrieved from https://kids4thecity.gr/

Konstantopoulos, M. A. (2017, May). Whispers... in the First Cemetery. (in Greek). Retrieved from https://www.efsyn.gr/ellada/koinonia/109364 psithyroi-stoproto-nekrotafeio 
Lambrou, Chr. (2020). Using necropolises/cemeteries in the educational process; Students' and teachers' perceptions in Primary Education. The case of the First Cemetery of Athens. (Diploma thesis). Hellenic Open University, Patras. Available from the Repository of Hellenic Open University (Code 49657) (in Greek).

Mendoza, I. (2015). The ABC's of Phobias. San Francisco: Blurb.

Mentzini, M. (2005, March-April). The cities of the dead. Technical chronicles, 72, 85-89. (in Greek).

Retrieved

from

http://library.tee.gr/digital/techr/2005/techr 20052 mentzini.pdf

Metallinos, G. D. (n.d.). Burial or cremation? (in Greek). Retrieved from https://www.impantokratoros.gr/E0BC1858.el.aspx

Meyer, E. (n.d.). Coimetrophobia: The Fear of Cemeteries. Retrieved from https://www.everplans.com/articles/coimetrophobia-the-fear-of-cemeteries

Miles, M. \& Huberman, A. M. (1994 2nd ed). Qualitative data analysis, an expanded sourcebook. London: Sage

Mount Auburn Cemetery. (n.d.). Retrieved from https://mountauburn.org/?cache

Nakou, E. (2001). Museum: Us, Things and Culture. Athens: Island (in Greek).

National Cemetery Administration. (n.d.). Retrieved from https://www.cem.va.gov/cem/legacy/docs/College Resource Guide 3-24-16.pdf

O'Connor, C., Michaels, S., Chapin, S., \& Harbaugh, A. G. (2017). “The silent and the vocal: Participation and learning in whole-class discussion". Learning and Instruction, 48: 5-13. doi: 10.1016/j.learninstruc.2016.11.003.

$\begin{array}{lllll}\text { Odysseus. (n.d.a). (in Greek). Retrieved } & \text { from }\end{array}$ http://odysseus.culture.gr/h/3/gh351.jsp?obj_id=2392

$\begin{array}{lllll}\text { Odysseus. (n.d.b). (in Greek). Retrieved } & \text { from }\end{array}$ http://odysseus.culture.gr/h/3/gh352.jsp?obj id=2573

$\begin{array}{lllll}\text { Odysseus. (n.d.c). (in Greek). Retrieved } & \text { from }\end{array}$ http://odysseus.culture.gr/h/1/gh151.jsp?obj id=3297

Paraskevopoulou, I. (2015). The First Cemetery of Athens. Historical visions 1834-2013. Athens: Polis (in Greek).

Parkes, C. M., Laungani, P. \& Young, B. (1997). A conceptual framework: historical and cultural themes. In C. M. Parkes, P. Laungani \& B. Young (Eds.), Death and Bereavement Across Cultures (pp. 3-26). London and New York: Routledge.

Parrott, W. G. (2001). Emotions in Social Psychology. Philadelphia: Psychology Press.

Pere Lachaise. (n.d.). Retrieved from https://pere-lachaise.com/

Petropoulou, E. (2018). Seeking new ways to interact with art and the approach of infants and first graders at the Museum of the Royal Tombs of Aigai. (Diploma thesis). Hellenic Open University, Patras. Available from the Repository of Hellenic Open University (Code 38766) (in Greek).

Politis, N. (2012). Traditions. Athens: Letters (in Greek).

Regulation for the Operation of Municipal Cemeteries of Ermionida. (n.d.). (in Greek). Retrieved from http://www.dimosermionidas.gr/\%CF\%80\%CE\%BF\%CE\%BB\%CE\%B9\%CF\%84 
\%CE \%B5\%CF $\% 83 / \% \mathrm{CE} \% \mathrm{~B} 4 \% \mathrm{CE} \% \mathrm{~B} 7 \% \mathrm{CE} \% \mathrm{BC} \% \mathrm{CE} \% \mathrm{BF} \% \mathrm{CF} \% 84 \% \mathrm{CE} \% \mathrm{~B} 9 \mathrm{CE}$ $\% \mathrm{BA} \% \mathrm{CE} \% \mathrm{~B} 1-$ \%СE $\% \mathrm{BA} \% \mathrm{CE} \% \mathrm{BF} \% \mathrm{CE} \% \mathrm{~B} 9 \% \mathrm{CE} \% \mathrm{BC} \% \mathrm{CE} \% \mathrm{~B} 7 \% \mathrm{CF} \% 84 \% \mathrm{CE} \% \mathrm{~B} 7 \% \mathrm{CF} \% 81 \% \mathrm{CE}$ \%B9\%CE\%B1.html

Robson, C. (2007). Real-world research: A tool for social scientists and professional researchers (2nd ed.). Athens: Gutenberg (in Greek).

Rosenblatt, P. C. (2008). Grief across cultures: A review and research agenda. In M. S. Stroebe, R. O. Hansson, H. Schut, \& W. Stroebe (Eds.), Handbook of bereavement research and practice: Advances in theory and intervention (pp. 207-222). American Psychological Association. https://doi.org/10.1037/14498-010

Rovva, K. (2018). "Mnemouria" in Skiathos. (in Greek). Retrieved from https://www.in.gr/2018/05/14/culture/texni/ta-mnimouria-sti-skiatho-anamesasta-istorika-koimitiria-tis-eyropis/

Skoubourdi, A. (2006). Athens, a magical city. Athens: Sideris (in Greek).

Skrivanos, T. (2017, April 12). First Cemetery of Athens. Guided tour of one of the most important open sculpture museums in Europe. Athens Voice, vol. 610. (in Greek). Retrieved from https://www.athensvoice.gr/life/urbanculture/athens/349376 nekrotafeio-athinon

Sophocles. (n.d.). Antigone. Pages for Antigone from Friedrich Holderlin, Soren Kierkegaard, Martin Heidegger. (trans. S. Stampoulou). Athens: Gutenberg (in Greek).

Spanakou, Z. (2019). Homeric epics: Iliad. Athens: Textbook Publishing Organization (in Greek).

Stefanou, I., \& Stefanou, I. (2001, September). The site of the dead in today's city. Archeology and Arts, 80, 46-52. (in Greek). Retrieved from https://www.archaiologia.gr/wp-content/uploads/2011/07/80-10.pdf

Stroebe, M. S., \& Schut, H. (2001). Models of coping with bereavement: A review. In M. S. Stroebe, R. O. Hansson, W. Stroebe, \& H. Schut (Eds.), Handbook of bereavement research: Consequences, coping, and care (pp. 375-403). American Psychological Association.

Symeou, L. (2007). Validity and reliability in qualitative educational research. In D. Chatzidimou (Ed). Proceedings of the 5 ht Greek Conference of Greek Pedagogical Society, Vol. 2, (pp. 333-339). Thessaloniki: Kyriakidis (in Greek).

The cemetery of Skiathos, a glyptotheque of memory. (2018). (in Greek). Retrieved from https://www.thetoc.gr/politismos/article/to-koimitirio-tis-skiathou-miagluptothiki-mnimis

The city of the dead. (2016, May). (in Greek). Retrieved from https://www.archaiologia.gr/blog/2016/05/31/\%CE\%B7$\% \mathrm{CF} \% 80 \% \mathrm{CF} \% 8 \mathrm{C} \% \mathrm{CE} \% \mathrm{BB} \% \mathrm{CE} \% \mathrm{~B} 7-\% \mathrm{CF} \% 84 \% \mathrm{CF} \% 89 \% \mathrm{CE} \% \mathrm{BD}-$ $\% \mathrm{CE} \% \mathrm{BA} \% \mathrm{CE} \% \mathrm{~B} 5 \% \mathrm{CE} \% \mathrm{BA} \% \mathrm{CE} \% \mathrm{BF} \% \mathrm{CE} \% \mathrm{~B} 9 \% \mathrm{CE} \% \mathrm{BC} \% \mathrm{CE} \% \mathrm{~B} 7 \% \mathrm{CE} \% \mathrm{BC} \% \mathrm{C}$ $\mathrm{E} \% \mathrm{AD} \% \mathrm{CE} \% \mathrm{BD} \% \mathrm{CF} \% 89 \% \mathrm{CE} \% \mathrm{BD} /$

Tsiolis, G. (2017). Thematic analysis of quality data. Patras: Hellenic Open University (in Greek). 
Tzinevraki, F. (n.d.). Cemeteries as operators of political management of bodies: The example of the First and the Third Cemetery. Academia.edu. (in Greek). Retrieved from

https://www.academia.edu/13810476/\%CE\%A4\%CE\%B1 \%CE\%BD\%CE\%B5\%C E\%BA\%CF\%81\%CE\%BF\%CF\%84\%CE\%B1\%CF\%86\%CE\%B5\%CE\%AF\%CE\%B1 $\% \mathrm{CF} \% 89 \% \mathrm{CF} \% 82 \% \mathrm{CF} \% 86 \% \mathrm{CE} \% \mathrm{BF} \% \mathrm{CF} \% 81 \% \mathrm{CE} \% \mathrm{~B} 5 \% \mathrm{CE} \% \mathrm{AF} \% \mathrm{CF} \% 82 \% \mathrm{CF}$ \%80\%CE\%BF\%CE\%BB\%CE\%B9\%CF\%84\%CE\%B9\%CE\%BA\%CE\%AE\%CF\%82 \%CE $\%$ B4\%CE\%B9\%CE\%B1\%CF\%87\%CE\%B5\%CE\%AF\%CF\%81\%CE\%B9\%CF\% 83\%CE\%B7\%CF\%82 \%CF\%84\%CF\%89\%CE\%BD \%CF\%83\%CF\%89\%CE\%BC\% CE\%AC\%CF\%84\%CF\%89\%CE\%BD \%CE\%A4\%CE\%BF \%CF\%80\%CE\%B1\%CF $\% 81 \% \mathrm{CE} \% \mathrm{AC} \% \mathrm{CE} \% \mathrm{~B} 4 \% \mathrm{CE} \% \mathrm{~B} 5 \% \mathrm{CE} \% \mathrm{~B} \% \mathrm{CE} \% \mathrm{B3} \% \mathrm{CE} \% \mathrm{BC} \% \mathrm{CE} \% \mathrm{~B} 1 \% \mathrm{CF} \% 84$ $\% \mathrm{CE} \% \mathrm{BF} \% \mathrm{CF} \% 85 \% \mathrm{CE} \% \mathrm{A0} \% \mathrm{CF} \% 81 \% \mathrm{CF} \% 8 \mathrm{E} \% \mathrm{CF} \% 84 \% \mathrm{CE} \% \mathrm{BF} \% \mathrm{CF} \% 85 \% \mathrm{CE}$ \%BA $\%$ CE $\%$ B1\%CE\%B9 \%CE\%A4\%CF\%81\%CE\%AF\%CF\%84\%CE\%BF\%CF\%85 $\% \mathrm{CE} \% \mathrm{BD} \% \mathrm{CE} \% \mathrm{~B} 5 \% \mathrm{CE} \% \mathrm{BA} \% \mathrm{CF} \% 81 \% \mathrm{CE} \% \mathrm{BF} \% \mathrm{CF} \% 84 \% \mathrm{CE} \% \mathrm{~B} 1 \% \mathrm{CF} \% 86 \% \mathrm{CE}$ \%B $\%$ CE $\%$ AF $\%$ CE\%BF\%CF\%85

Venit, M. (1988). The Painted Tomb from Wardian and the Decoration of Alexandrian Tombs. Journal of the American Research Center in Egypt, 25, 71-91. doi: $10.2307 / 40000871$

Vourvachis, E. A. (2007). The naval battle of Arginousa. The trial and death sentence of the Athenian Generals (406 BC). Athens: Enalios (in Greek).

Walter, T. (1997). Secularization. In C. M. Parkes, P. Laungani \& B. Young (Eds.), Death and Bereavement Across Cultures (pp. 166-190). London and New York: Routledge.

Zafeirakou, A. (2000). Museums and Schools: Dialogue and collaborations, Representations and Practices. In: A. Zafeirakou (ed.), Museums and Schools: Dialogue and Collaborations, Representations and Practices ( $\sigma \varepsilon \lambda .17-34)$. Athens: Typothito / George Dardanos (in Greek).

Zavraka, D. (2009, September). The urban dimension of European landfills. Comparative analysis of the public character of modern cemeteries in France and Switzerland. Announcement at the $2^{\text {nd }}$ Panhellenic Conference on Urban Planning, Spatial Planning and Regional Development, Volos. (in Greek). Retrieved from http://library.tee.gr/digital/m2501 2600/m2525/m2525 zavraka.pdf

Ziro, O. (2014). The tomb relief in modern Greek sculpture (1830-1900): the narration of the figures. (Doctoral dissertation, National Kapodistrian University of Athens). Available from the National Archive of Doctoral Dissertations (Cod. 38186) (in Greek). 
Author(s) will retain the copyright of their published articles agreeing that a Creative Commons Attribution 4.0 International License (CC BY 4.0) terms will be applied to their work. Under the terms of this license, no permission is required from the author(s) or publisher for members of the community to copy, distribute, transmit or adapt the article content, providing a proper, prominent and unambiguous attribution to the authors in a manner that makes clear that the materials are being reused under permission of a Creative Commons License. Views, opinions and conclusions expressed in this research article are views, opinions and conclusions of the author(s). Open Access Publishing Group and European Journal of Education Studies shall not be responsible or answerable for any loss, damage or liability caused in relation to/arising out of conflicts of interest, copyright violations and inappropriate or inaccurate use of any kind content related or integrated into the research work. All the published works are meeting the Open Access Publishing requirements and can be freely accessed, shared, modified, distributed and used in educational, commercial and non-commercial purposes under a Creative Commons Attribution 4.0 International License (CC BY 4.0). 